
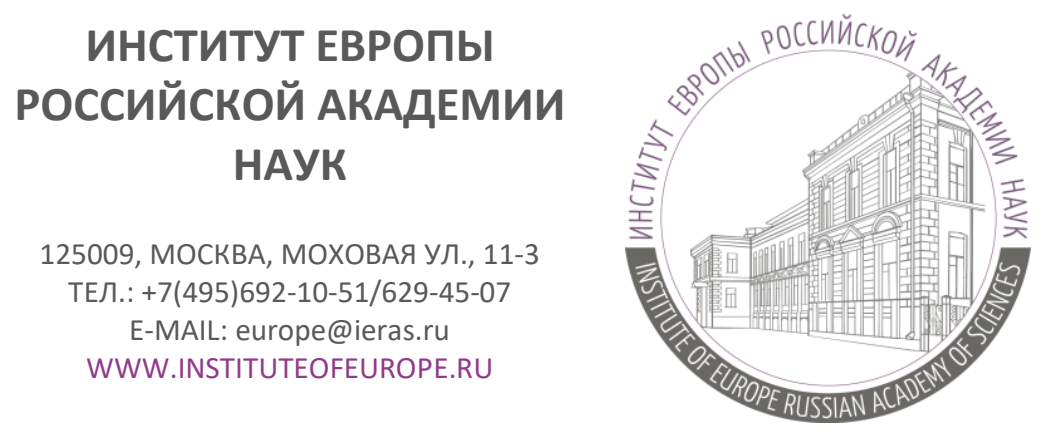

INSTITUTE OF EUROPE RUSSIAN ACADEMY OF SCIENCES

125009, MOSCOW, MOKHOVAYA STR., 11-3

TEL.: +7(495)692-10-51/629-45-07

E-MAIL: europe-ins@mail.ru WWW.INSTITUTEOFEUROPE.RU

Аналитическая записка №26, 2020 (№209) ${ }^{1}$

\title{
Работа институтов ЕАЭС в условиях коронакризиса
}

\section{Наталия Борисовна Кондратьева}

кандидат экономических наук, ведущий научный сотрудник, руководитель Центра экономической интеграции Отдела исследований европейской интеграции, ученый секретарь Института Европы РАН

\begin{abstract}
Аннотация. Автор анализирует меры, принятые институтами ЕАЭС на начальной стадии борьбы с пандемией коронавируса. Выявлено стремление компенсировать меры по локализации пандемии шагами, направленными на либерализацию передвижения мобильных трудящихся и товаров целевого назначения, а также смещение торговых потоков внутрь группировки. Прогнозируется углубление интеграџи: ограничение односторонних действий, проведение скоординированной политики, сохранение принципов организации внутреннего рынка, прежде всего, свободы передвижения факторов и результатов экономической деятельности.
\end{abstract}

Ключевые слова: коронакризис, локализация пандемии, председательство Беларуси, Стратегические направления развития евразийской экономической интеграции до 2025 года, ЕАЭС, Евразийская экономическая комиссия (ЕЭК).

\footnotetext{
${ }^{1}$ DOI: http://doi.org/10.15211/analytics262020
} 
Начальная стадия коронакризиса в странах ЕАЭС (результат пандемии инфекции COVID-19) характеризуется такими проявлениями, как неуверенность экономических акторов и рост неопределенности. Прогнозируется смещение сроков выполнения госзаказов, падение загрузки производственных мощностей, снижение производительности труда, доходов, спроса на услуги. Ситуация усугубляется падением цен на нефть ниже уровня начала 2016 г. Тогда это привело к значительному сокращению совокупного ВВП Союза, на преодоление спада ушло два года ${ }^{2}$. В Беларуси, внешняя торговля которой на $53 \%{ }^{3}$ ориентирована на ЕАЭС, восстановление заняло три года. Нынешний более глубокий, хотя и менее продолжительный, обвал цен и ослабление национальных валют стран ЕАЭС также неизбежно приведут к дефициту средств на восстановление экономик.

В первые месяцы пандемия еще не успела сказаться на производственной сфере, но, как и везде в мире, приостановила оказание многих услуг: туристических, авиаперевозок, досуга. Количественные потери уже сегодня значительны с учетом долей замерзших услуг в экономике, непредвиденных расходов на экстренные меры, недополученных доходов от продаж углеводородов (в том числе сокращения их потребления), несостоявшихся сезонных работ в сельском хозяйстве и сезонной мобильности. Кризис, напомнив об оборотой стороне глобализации, дал повод для переоценки места наднационального и государственного уровня власти в регулировании экономики.

\section{Оперативные меры реагирования на кризис}

Коронакризис стал вызовом для евразийской интеграции, но не остановил ее. Работа институтов была скорректирована с учетом необходимости урегулирования актуальных проблем взаимной торговли. Усилия ЕЭК совместно с правительствами были направлены на обеспечение экономической стабильности и борьбу с распространением инфекции. На фоне пандемии четко обозначил себя приоритет сотрудничества государств ЕАЭС - регулирование передвижения факторов и результатов экономической деятельности. Решения по локализации вируса и ограничению передвижения людей компенсировались временными мерами по либерализации торгового режима и смещению торговых потоков внутрь группировки.

Одно из первых решений Совета ЕЭК, принятое в середине марта - упрощение таможенных процедур для критически важных товаров и освобождение от ввозных пошлин медицинских и других изделий, импортируемых на таможенную территорию

\footnotetext{
2 Мировой кризис 2020: вызовы для мира и ЕАЭС. Опыт выхода из кризиса 2014/15 годов. Аналитическая записка на сайте ЕЭК. 31.03.2020

${ }^{3}$ Доклад о состоянии взаимной торговли между государствами-членами Евразийского экономического союза в 2018 г. ЕЭК. 2018. С. 27. URL:

http://www.eurasiancommission.org/ru/act/integr_i_makroec/dep_stat/tradestat/analytics/Documents/report/Rep ort_2018.pdf (дата обращения: 26.04.2020)
} 
ЕАЭС для борьбы с распространением COVID-19. Следующим стало решение о запрете вывоза с таможенной территории продукции целевого назначения. Во втором пакете мер в апреле было решено включить некоторые продовольственные товары (крупы и овощи) в список продукции, на который распространяется временное освобождение от ввозных пошлин и временный запрет на экспорт за пределы Союза.

Удалось избежать неразберихи с транзитными автомобильными грузоперевозками. В целом сохранено сообщение по железным дорогам и водным маршрутам. Главное, нет ничего подобного тому, что наблюдалось в марте 2020 года на многих границах внутри Евросоюза. Как только там начали застревать белорусские перевозчики грузов из ЕС в Россию, Беларусь стала отслеживать транспортную составляющую кризиса и фиксировать все изменения в режиме транспортировки транзитных грузов. Что касается передвижения внутри таможенной территории ЕАЭС, то ни одна страна не пошла на применение односторонних мер: для грузового автотранспорта из государствчленов была сохранена свобода передвижения при условии использования водителями средств индивидуальной зашиты и соблюдения правил личной гигиены. После введения 15 апреля заявительного порядка передвижений по Москве и Московской области водители из государств-членов наравне с российскими гражданами, продолжающими работать в штатном режиме, при заказе пропуска указывают ИНН работодателя. Пропуск выдается без ограничения количества поездок и маршрутов передвижения.

Новое для правоохранительных структур направление - временное ограничение свободы передвижения людей - компенсировано мерами временной либерализации требований к гражданам стран ЕАЭС по нахождению на территории. В частности, Указ Президента РФ от 18 апреля 2020 года № 274 признает такое нахождение законным и предоставляет отсрочку регистрации на период пандемии.

\section{Складывающиеся условия}

10 апреля участники заседания Евразийского межправительственного совета высказались по поводу новых условий следующим образом: «Главной задачей должно стать формирование дополнительных заделов устойчивости не только в рамках национальных экономик, но и в рамках всего ЕАЭС» ${ }^{4}$. По итогам заседания принято распоряжение, которое обобщило возможные меры экономической стабилизации в условиях развития пандемии. В числе приоритетов: общая торговая, промышленная и транспортная политики, функционирование внутреннего рынка и его цифровизация, продовольственное самообеспечение, финансовые рынки и денежно-кредитная политика. Важной задачей названо переосмысление роли Евразийского банка развития и Евразийского фонда стабилизации и развития в улучшении макроэкономической

4 Заседание Евразийского межправительственного совета. 10 апреля 2020 URL: http://government.ru/news/39472/ (дата обращения: 05.04.2020) 
ситуации после кризиса. Учитывая замирание на рынке труда, во всех странах Союза увеличена господдержка наиболее уязвимых слоев населения и бизнеса, не имеющего запаса прочности.

Пандемия повысила спрос на каналы обмена информацией и онлайн торговлю, подстегнула рост цифровой грамотности населения, стимулировала переоценку компаниями соответствующих активов и возможностей, оптимизацию за счет сокращения одних и возникновения других сфер приложения труда, обнажила потребности отраслей и застарелые проблемы дефицита интернет-связи в регионах.

Развитие коронакризиса в ЕАЭС ускоряет процедуру принятия решений с акцентом на безусловную взаимную помощь и отказ от односторонних мер. «Обращает на себя внимание именно союзный подход, откровенно контрастирующий с европейским, где члены «единой Европы» буквально выгрызали маски друг у друга, не гнушаясь откровенным воровством и грабежом», - такой комментарий приводит сайт ЕАБР (обсуждается участия Банка в проектах по восстановлению после коронакризиса).

Налажен ежедневный мониторинг ${ }^{6}$ эпидемиологической ситуации и принимаемых в каждом государстве мер по стабилизации и господдержке экономики. Они публикуются нарастающим итогом на сайте ЕЭК. Открытость материалов позволяет провести их сравнительную оценку и стимулирует координацию денежно-кредитной политики.

\section{Приоритеты председательства Беларуси}

Планы председательства Беларуси в органах Евразийского союза ${ }^{7}$ с 1 января 2020 года не были прерваны. Наоборот, коронакризис дал дополнительный импульс важнейшим инициативам председательства: переходу к общей политике в промышленности, сельском хозяйстве, энергетике, транспорте, к устранению препятствий во взаимной торговле, укреплению сотрудничества в научно-технической и инновационной сферах. Кризис обострил понимание взаимозависимости, необходимости координации действий и ускорения интеграционных процессов. Но станут ли экономические последствия коронакризиса триггером углубления интеграции?

В целом, да, если судить по тому, что пандемия не помешала реализации стратегических планов. Проект Стратегических направлений развития евразийской экономической интеграции до 2025 года прошел процедуру согласования. Он содержит более 300 конкретных мер по устранению барьеров, изъятий и снятию ограничений,

5 ЕАЭС против коронавируса: взаимопомощь и системный подход. 21 апреля 2020 URL: https://eabr.org/press/news/eaes-protiv-koronavirusa-vzaimopomoshch-i-sistemnyy-podkhod/ (дата обращения: 05.04.2020)

${ }^{6}$ Мониторинг мер стран ЕАЭС. URL: http://www.eurasiancommission.org/ru/covid-19/pages/monitoring.aspx

${ }^{7}$ Высший Евразийский экономический совет (ВЕЭС), Евразийский межправительственный совет, Совет ЕЭК. 
таможенному регулированию, гарантиям обеспечения качества и безопасности товаров, защите прав потребителей, продвижению проектов с высокой интеграционной составляющей. Реализация Стратегии предусматривает подготовку 13 международных договоров, более 60 нормативно-правовых актов ЕАЭС, около 25 изменений и дополнений в Договор о Союзе, а также изменения в национальных законодательствах государств-членов.

Проектом, который пока не открыт для широкой общественности, предусмотрено заметное расширение деятельности институтов. В частности, компетенция ЕЭК будет распространена на сферы здравоохранения, науки, образования. Это необходимо для более эффективного контроля за предоставлением услуг и защиты прав их потребителей. Если кризис не будет разгораться, положения Стратегии вряд ли будут пересмотрены.

Еще до начала пандемии были запланированы две ключевых даты для принятия стратегического документа: 23 апреля и 19 мая 2020 года. 23 апреля на заседании Межправительственного совета ${ }^{8}$ были урегулированы последние несогласованные вопросы: о поэтапной либерализации международных автомобильных перевозок, о гибких механизмах целевого содействия экономическому развитию государств-членов ЕАЭС и о расширении сотрудничества в области здравоохранения. Проект Стратегии, как и задумывалось, был в целом одобрен 19 мая Высшим Евразийским экономическим советом на уровне глав государств, хотя и без решения по тарифам на транспортировку газа на общем рынке ЕАЭС (с предложенной формулой не согласны Армения и Беларусь). Для окончательного принятия документа предусмотрена еще одна встреча на высшем уровне (осенью в очном формате).

\section{Выводы}

Усилия институтов ЕАЭС на начальном этапе коронакризиса были направлены, вопервых, на либерализацию таможенного режима в отношении товаров целевого назначения, во-вторых, на переориентацию внутрь группировки критически важных торговых потоков, в-третьих, на поддержание стабильной работы грузового транспорта с целью недопущения роста цен и дефицита товаров, в-четвертых, на упрощение режима пребывания мобильных граждан.

При условии принятия новых стратегических направлений деятельности ЕАЭС до 2025 года возможны более глубокие меры экономического регулирования во имя поддержания взаимной торговли и кооперации. Вероятно дальнейшее снижение таможенных пошлин на комплектующие и материалы для экономически и социально значимых отраслей. 14 апреля на рабочем заседании ВЕЭС (где было принято совместное заявление глав государств в связи с пандемией) об этой перспективе

\footnotetext{
${ }^{8}$ Вопрос о тарифах по газу вынесен на Высший совет ЕАЭС. 23.04.2020 URL: https://rg.ru
} 
говорил Президент РФ В.В. Путин ${ }^{9}$, указавший на востребованность взаимодействия центробанков государств-членов по вопросам кредитования предприятий реального сектора, расширения безналичных платежей и дистанционного получения банковских услуг ${ }^{10}$. Вероятна переоценка роли таких инвестиционных инструментов, как ЕАБР и Евразийский стабилизационный фонд, с учетом созданных коронакризисом новых условий хозяйствования (здесь отчасти востребован пятилетний опыт Европейского фонда стратегических инвестиций ЕС).

Но кризис все-таки дает о себе знать. Итоги встречи на высшем уровне 19 мая показали, что настрой союзников на интеграцию определяется объемом преференций со стороны РФ, несмотря на то что она гораздо больше других пострадала от пандемии (разногласия по условиям транспортировки газа отдалили подписание Стратегии развития Союза).

В условиях коронакризиса целесообразно провести промежуточную оценку действия национальных проектов по цифровизации, включая сервисы электронных правительств государств ЕАЭС, учреждений сферы здравоохранения и образования. В рамках дальнейшей помощи малым и средним предприятиям можно было бы содействовать развитию удаленного режима работы: в частности, предусмотреть субсидии на установку необходимого оборудования (как уже сделано в Японии).

Необходимо выявлять лучшие мировые практики господдержки занятости населения. Одна из них - выплата самозанятым лицам субсидий или пособий на уровне их заявленного дохода в предыдущем налоговом году. Такую меру применили в Германии. Интерес представляет практика выплат пособий по болезни, примененная в США.

Наиболее вероятным становится сценарий углубления евразийской интеграции. Это означает проведение государствами-членами скоординированной политики, отказ от односторонних мер, способных вызвать неразбериху и усугубить экономический спад.

Annotation. The author assesses the rapid response of EAEU institutions to the initial stage of corona crisis. An analogy is drawn with the monetary crisis of 2014-2016, which led to significant reduction of the Union's total GDP. The institutions focus on balancing the measures aimed at localizing the pandemic with the measures aimed at liberalizing the regime of mobile workers and movement of targeted goods. Another focus is on shifting target trade flows inside the group. The trend for deeper integration is likely to continue by limiting unilateral actions, coordinating policies, and maintaining

9 Итоги рабочей встречи и совместное заявление членов ВЕЭС. 14 апреля 2020 г. URL: http://www.eurasiancommission.org/ru/nae/news/Pages/14-04-2020-2.aspx (дата обращения: 26.04.2020)

10 Встреча Членов Высшего Евразийского Экономического Совета. 14 апреля 2020 года URL: http://kremlin.ru/events/president/news/page/15 (дата обращения: 26.04.2020) 
the principles of internal market organization, first of all, the freedom of movement of factors and results of economic activity.

Keywords: corona crisis, localization of the pandemic, Belarus' presidency, Strategic lines for the development of the Eurasian economic integration until 2025, EAEU, Eurasian Economic Commission (EEC)

Дата выпуска: 23 мая 2020 года.

Материал доступен для скачивания по адресу: www.instituteofeurope.ru/publications/analytics 